\title{
Relationship between tidewater glacier calving velocity and water depth at the calving front
}

\author{
Mauri S. Pelto \\ Nichols College, Dudley, MA 01571, U.S.A. \\ Charles R. Warren \\ Department of Geography, University of Edinburgh, Edinburgh EG8 9XP, Scotland, U.K.
}

\begin{abstract}
An analysis of the relationship between iceberg calving rates and water depth has been completed for 22 tidewater glaciers. A linear relationship provides reasonable accuracy, with a correlation coefficient of 0.85 , for all tidewater glaciers examined, whether they be polar or temperate. The polar glaciers have a slightly lower calving rate for a given water depth. This relationship indicates a lower calving rate for water depths over $50 \mathrm{~m}$ than determined by Brown and others (1982). It is based only on glaciers or ice streams and cannot be applied to ice shelves.
\end{abstract}

\section{INTRODUCTION}

The aim of this paper is to update the database of iceberg calving rates and water depths at the termini of tidewater glaciers, and to provide an accurate empirical relationship between the two. As noted by Meier and Post (1987), there are two primary types of tidewater glacier, temperate grounded glaciers and polar glaciers which may have floating termini. In a landmark study of Alaskan tidewater glaciers, Brown and others (1982) demonstrated that the water depth at the glacier front provides a good first estimate of calving rate for tidewater glaciers. Funk and Röthlisberger (1989) gave a calving rate-water depth relationship for fresh-water calving glaciers. In recent years, the Brown and others (1982) relationship has been widely applied to other glaciers. However, on 9 of the 13 glaciers used in their study, calving rate was measured during a single ablation season, giving summer rates, not annual calving rates. Measurement of annual velocity on several of the same glaciers has indicated significant differences between annual and summer calving rates (Meier and others, 1985). For accurate mass balance assessment, an equation estimating annual calving rate is required. In this study, summer and annual calving rates are considered in establishing a calving rate-water depth relationship.

\section{CALVING RATE DATA}

Calving rate and water depth data from 22 glaciers are analyzed. Calving rate $\left(V_{\mathrm{c}}\right)$ is defined simply as

$$
V_{\mathrm{c}}=V_{\mathrm{i}}+V_{\mathrm{r}}
$$

where $V_{\mathrm{i}}$ is the ice velocity and $V_{\mathrm{r}}$ is the rate of retreat. The data are derived from 11 grounded temperate glaciers, 7 grounded polar glaciers, and 4 floating polar glaciers. Additional data are provided by the different dates of measurement on Columbia Glacier in Alaska, which represent significantly different terminus positions and water depths. Table 1 presents the data for each glacier: calving rates, water depths, calving rate measurement errors and percentage of the glacier thickness that is buoyant. The data span is a continuous period of months, except on Kongsvegen, which was observed periodically for 18 months. Data are excluded if the water depth is unknown, as in the case for most West Greenland glaciers. Temperate glacier data are also excluded if the observation period does not exceed one month, as is the case for Yale, Muir and Harvard Glaciers in Alaska, and San Rafael Glaciar in Patagonia.

\footnotetext{
Alaska

The calving rate at the front of Lituya, Johns Hopkins, Margerie, North Crillon and South Sawyer Glaciers has been determined by satellite tracking of salient medial moraine features, both in the centre and near the lateral margins of the glaciers. Distinctive moraine features were chosen because of the difficulty in tracking crevasse zones; sharp bends and changes in moraine width are particularly useful. To reduce the error and increase the reliability of the derived calving rates, data were gathered over two separate one year periods (Table 2). The spatial resolution of Landsat 4 and 5 Thematic Mapper (TM) imagery is $30 \mathrm{~m}$, limiting the accuracy of velocity calculations and the number of features that can be used. However, because of the large amount of annual displacement $\left(300-1800 \mathrm{~m} \mathrm{a}^{-1}\right)$, the error in velocity
} 
Pelto and Warren: Glacier calving velocity and water depth

Table 1. Water depth at the calving front $\left(H_{\mathrm{w}}\right)$, glacier velocity at the calving front $\left(V_{\mathrm{c}}\right)$, error in velocity determination, percentage of the glacier thickness that is buoyant $\left(H_{\mathrm{b}}\right)$, duration of velocity measurements, and the data source (first author only).

\begin{tabular}{|c|c|c|c|c|c|c|}
\hline Glacier & $\begin{array}{l}H_{\mathrm{w}} \\
(\mathrm{m})\end{array}$ & $\begin{array}{c}V_{\mathrm{c}} \\
\left(\mathrm{m} \mathrm{a}^{-1}\right)\end{array}$ & $\begin{array}{l}\text { Error } \\
\left(\mathrm{m} \mathrm{a}^{-1}\right)\end{array}$ & $\begin{array}{l}H_{\mathrm{b}} \\
(\%)\end{array}$ & $\begin{array}{c}\text { Data span } \\
\text { (months) }\end{array}$ & Source \\
\hline \multicolumn{7}{|l|}{ Alaska } \\
\hline Columbia, 1978 & 75 & 2185 & 100 & 47 & 12 & Brown and others, 1982 \\
\hline Columbia, 1982 & 140 & 3100 & 100 & 72 & 12 & Meier and others, 1985 \\
\hline Grand Pacific & 20 & 220 & 70 & 30 & 23 & Brown and others, 1982 \\
\hline Hubbard & 100 & 2600 & 200 & 50 & 12 & Brown and others, 1982 \\
\hline Johns Hopkins & 60 & 800 & 200 & 46 & 22 & This study \\
\hline Lituya & 70 & 550 & 200 & 33 & 22 & This study \\
\hline Mc'Carty & 15 & 600 & 250 & 28 & 12 & Brown and others, 1982 \\
\hline Margerie & 20 & 365 & 100 & 20 & 22 & This study \\
\hline North Crillon & 35 & 640 & 100 & 48 & 22 & This study \\
\hline South Sawyer & 186 & 1800 & 300 & 78 & 24 & This study \\
\hline Tyndall & 70 & 1740 & 250 & 40 & 12 & Brown and others, 1982 \\
\hline \multicolumn{7}{|l|}{ West Greenland } \\
\hline Eqip Sermia & 200 & 850 & 250 & 70 & $\begin{array}{r}1 \\
12\end{array}$ & $\begin{array}{l}\text { Carbonnell and Bauer, } 1968 \\
\text { Pelto and others, } 1989\end{array}$ \\
\hline Jakobshavns Isbrae & 900 & 7700 & 150 & 100 & 12 & $\begin{array}{l}\text { Pelto and others, } 1989 \\
\text { Carbonnell and Bauer, } 1968\end{array}$ \\
\hline Kangerdluarrsup & 300 & 2600 & 250 & 100 & 1 & Carbonnell and Bauer, 1968 \\
\hline Lille Qarajaq & 150 & 500 & 100 & 65 & 1 & Carbonnell and Bauer, 1968 \\
\hline Rinks Isbrae & 800 & 4450 & 500 & 100 & 1 & Carbonnell and Bauer, 1968 \\
\hline Umiamako Isbrae & 260 & 1900 & 300 & 80 & 1 & Carbonnell and Bauer, 1968 \\
\hline \multicolumn{7}{|l|}{ Svalbard } \\
\hline Hansbreen & 30 & 230 & 40 & 50 & 24 & Jania, 1986 \\
\hline Kollerbreen & 50 & 110 & 40 & 100 & 4 & Wilhelm, 1963 \\
\hline Kongsbreen & 110 & 1100 & 50 & 36 & 2 & Pillewizer, 1965 \\
\hline Kongsvegen & 30 & 100 & 30 & 40 & 10 & Pillewizer, 1965 \\
\hline Mayerbreen & 30 & 240 & 50 & 40 & 1 & Wilhelm, 1963 \\
\hline
\end{tabular}

Table 2. Landsat TM scenes used in determining calving rate on Alaskan tidewater glaciers. SS $=$ South Sawyer, $\mathcal{F H}$ $=$ Johns Hopkins, $\mathcal{N C}=$ North Crillon, $M=$ Margerie, $L=$ Lituya.

\section{Image Scene Image Date Image Band Glaciers}

\begin{tabular}{lllll}
\hline 56 & 20 & Sep. 17, 1983 & 4 & SS \\
57 & 19 & Aug. 17, 1984 & 4 & SS \\
56 & 20 & Sep. 17, 1986 & 4 & SS \\
56 & 20 & Aug. 28, 1987 & 4 & SS \\
60 & 19 & Aug. 28, 1983 & 4 & JH, NC, M, L \\
60 & 19 & Jul. 21, 1984 & 4 & JH, NC, M, L \\
60 & 19 & Sep. 6, 1986 & 4 & JH, NC, M, L \\
60 & 19 & Aug. 24, 1987 & 4 & JH, NC, M, L \\
\hline
\end{tabular}

determination of $100 \mathrm{~m} \mathrm{a}^{-1}$ is regarded as acceptable. The other Alaskan glaciers used in the study are from Brown and others (1982).

\section{Greenland and Svalbard}

The other data analyzed in this study have been drawn from various published sources (Table 1) and were all obtained through direct field observations. In Greenland, annual calving rates are available only for Jakobshavns Isbræ and Sermeq Avangnardleq. There is no significant seasonal change in glacier velocity on Jakobshavns Isbræ (Echelmeyer and others, 1989; Pelto and others, 1989). This is not surprising; what known mechanism could, each winter, slow down a glacier $850 \mathrm{~m}$ thick moving at up to $20 \mathrm{~m} \mathrm{~d}^{-1}$ ? Velocities were noted on Sermeq Avangnardleq during the Jakobshavns Isbræ study directed by Terence Hughes, and no significant seasonal changes were observed (Sermeq Avangnardleq is not shown on Table 1 because no bathymetric data exist). It is, therefore, probable that the annual and summer calving speeds of large Greenland glaciers do not vary as much as temperate glaciers and, therefore, that Carbonnell and Bauer's (1968) data of only one month duration can be used as being indicative of annual calving rates. 


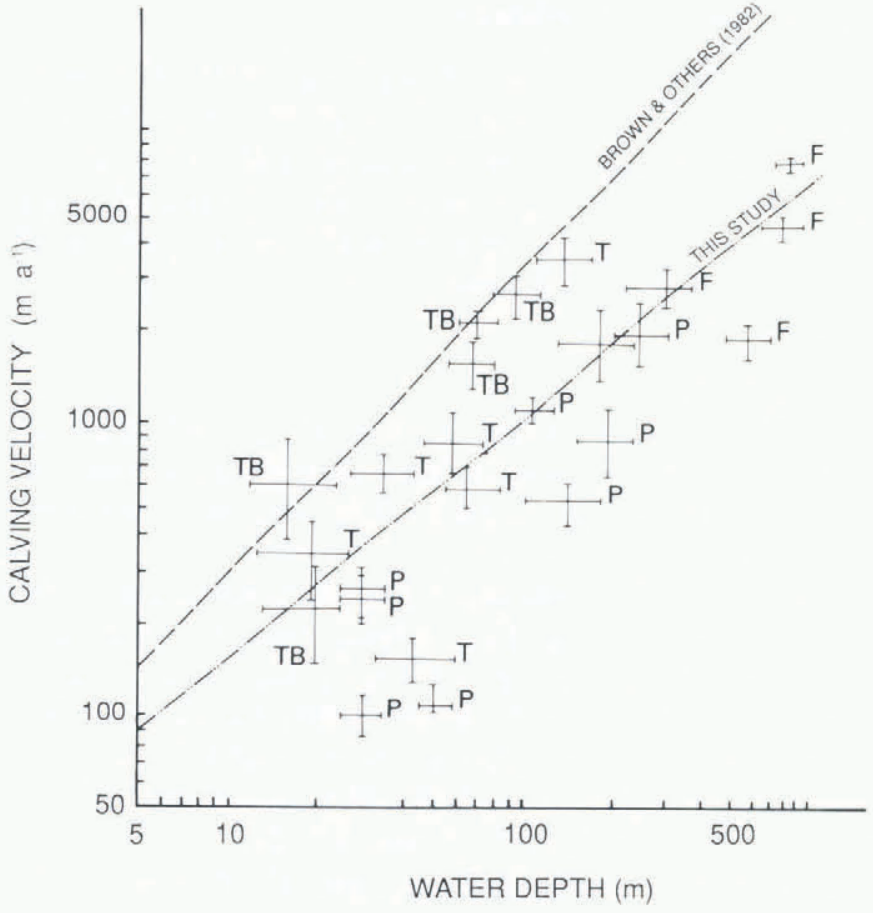

Fig. 1. The relationship between water depth and calving velocity is noted for tidewater glaciers world-wide. All input data are shown in Table 1. The relationship derived by Brown and others (1982) and that proposed in this study are also shown. The vertical lines represent the error bars in velocity determination; the horizontal bars represent the error in water depth measurement. $T=$ grounded temperate glacier, $P=$ grounded polar glacier, $F=$ floating polar glacier, TB $=$ grounded temperate glacier used by Brown and others (1982).

\section{RESULTS}

Figure 1 shows the water depth $\left(H_{\mathrm{w}}\right)$ and calving speed $\left(V_{c}\right)$ data, the relationship derived by Brown and others (1982), and that proposed in this study. The horizontal and vertical lines for each glacier represent the error bars in depth and velocity measurement, respectively. Linear regression analysis was used to establish a simple linear relationship between calving velocity and water depth

$$
V_{\mathrm{c}}=70\left[\mathrm{~m} \mathrm{a}^{-1}\right]+8.33\left[\mathrm{a}^{-1}\right] H_{\mathrm{w}},
$$

with a correlation coefficient of 0.85 and a standard deviation of $22 \%$. Standard deviation is expressed as a percentage because glacier velocities range over more than an order of magnitude. Least squares regression was also tested but did not give significant improvement over the linear relationship, and the number and accuracy of the data do not warrant using more rigorous statistical methods.

Only three glaciers in Figure 1 exhibit calving rates much in excess of that predicted by the proposed calving relationship: Mc'Carty, Columbia, and Tyndall Glaciers. Mc'Carty Glacier underwent a rapid calving retreat in the middle part of this century, and the Columbia and Tyndall Glaciers are experiencing catastrophic retreat at present. Two glaciers have calving rates much lower than those predicted: Kongsvegen and Kollerbreen in Sval-

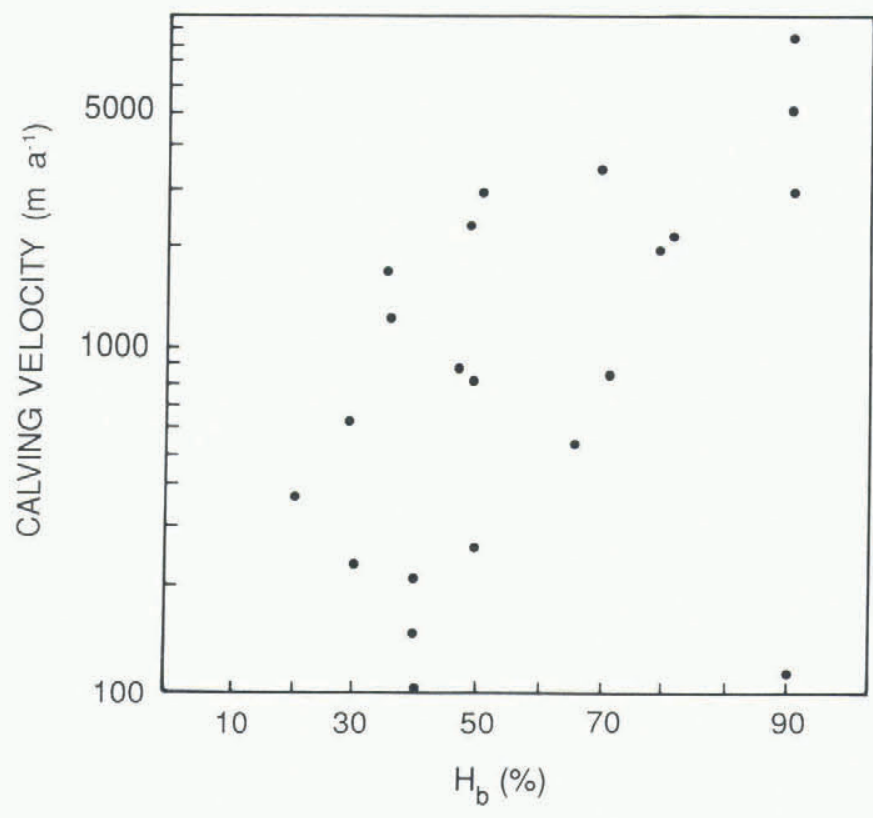

Fig. 2. The relationship between calving velocity and the percentage of the glacier thickness that is buoyant $\left(H_{b}\right)$ the calving front. A weak direct relationship exists.

bard. These two glaciers have shown large seasonal velocity fluctuations, and, since the data span for each glacier is less than a year, these figures may not be representative. Overall, the polar glaciers tend to have a lower calving rate, which is an expected result given the greater hardness of the ice, but may also be an artifact of the limited data sets.

In Figure 2, calving rate is related to the percentage of the glacier thickness that is supported by the buoyancy of the water column. The fit is not good, with a correlation coefficient of 0.61 . Table 3 presents a comparison of ablation season and annual calving velocities, and shows that substantial differences exist between summer and annual calving rates.

Table 3. Comparison of summer calving velocity $\left(V_{\mathrm{CS}}\right)$ and annual calving velocity $\left(V_{\mathrm{ca}}\right)$.

\begin{tabular}{lrrr} 
Glacier & $V_{\text {cs }}$ & $V_{\text {ca }}$ & Source \\
\hline Columbia & 2600 & 1400 & Meier and others, 1985 \\
Johns Hopkins & 2300 & 800 & Brown and others, 1982 \\
Margerie & 463 & 365 & Brown and others, 1982 \\
South Sawyer & 3200 & 1800 & Brown and others, 1982
\end{tabular}

Jakobshavn

Isbrae $\quad 6420 \quad 6240 \quad$ Pelto and others, 1989

Kongsvegen $\quad 110 \quad 70 \quad$ Pillewizer, 1965

Sermeq

Avangnardleq $540 \quad 530 \quad$ This study 


\section{DISGUSSION}

The correlation coefficient between calving velocity and water depth of 0.85 demonstrates again the direct linear relationship. The Brown and others (1982) relationship (Fig. 1) over-estimates annual $V_{c}$, but it probably provides a better fit for the maximum summer $V_{\mathrm{c}}$. Theoretically, a $V / H_{\mathrm{w}}$ relation is uncorrectable for floating termini, since it would predict increasing calving rates with increasing depth of water below the ice front, and this is unreasonable (Brown and others, 1982). Once a glacier is afloat, that part of the calving rate which is due to buoyancy forces is "fixed" at a maximum, and variations in calving rate and calving flux are controlled by factors other than water depth, such as changing velocity fields, tidal flexure (Lingle and others, 1981), seasonal freeze-up of the fjord, and strong seasonal changes of meltwater input (Hughes, 1986). However, these data suggest that a $V_{\mathrm{c}} / H_{\mathrm{w}}$ relationship does exist, although it cannot be a causal one. Is this a spurious result, due to limited data?

The fact that calving speeds are less closely related to buoyancy forces than water depth (Fig. 2) confirms the earlier dichotomy identified by Brown and others (1982). They proposed two calving laws; the first relates calving speeds to water depth and appears to match data spanning a year or more, whereas the second relates calving velocities to meltwater discharge and the height of the unsupported ice column, and provides a good fit for seasonal variation. There does not yet exist a general calving law which accurately fits both the detailed and general behaviour of grounded calving fronts, emphasizing the limited nature of our current understanding of the controls on calving dynamics. The water depth relation is a necessary but not a sufficient condition (Powell, 1984). If water depth changes, calving speed may change, but the inverse is not necessarily the case. It is still a moot point whether variables affecting calving speed or glacier velocity are most affected by changes in water depth.

The data presented here highlight the need for the following: (i) a more extensive database of calving statistics; (ii) longer observation periods in order to identify and take into account the seasonal fluctuations in calving speeds. Winter data for the large Greenland outlet glaciers would be of particular value.

\section{CONCLUSION}

Rates of iceberg calving for both temperate and polar grounded tidewater glaciers are dominantly controlled by the water depth at the terminus over periods of a year or more, for reasons not fully understood at present. Estimates of annual calving fluxes based only on ablation season data overestimate true annual rates. The current world wide database of calving statistics is remarkably limited. A separate relationship may be appropriate for temperate and polar glaciers, but this issue can only be answered with more data points. It is clear that unless tidewater glaciers in Alaska, Patagonia, South Georgia, and Greenland are monitored regularly, we will not be able to determine a general calving law nor understand how climatic warming may affect these glaciers.

\section{ACKNOWLEDGEMENTS}

Our understanding of tidewater glaciers is largely dependent on the extensive work of the USGS directed by M. Meier and A. Post in Alaska, and on the EGIG project directed by A. Bauer in West Greenland. This paper is an extension of their work. CRW was in receipt of a NERC (U.K.) Studentship.

\section{REFERENCES}

Brown, C.S., M.F. Meier, and A. Post. 1982. Calving speed of Alaska tidewater glaciers with applications to the Columbia Glacier, Alaska. U.S. Geol. Surv. Prof. Pap. 1258-C.

Brown, C.S., W.G. Sikonia, A. Post, L.A. Rasmussen, and M.F. Meier. 1983. Two calving laws for grounded iceberg-calving glaciers. (Abstract.) Ann. Glaciol., 4, 295.

Carbonnell, M. and A. Bauer. 1968. Exploitation des couvertures photographiques aériennes répétées du front des glaciers vêlant dans Disko Bugt et Umanak Fjord, juin - juillet 1964. Medd. Gronl., 173(5).

Echelmeyer, K., W. Harrison, and C. Benson. 1989. Dynamics of Jakobshavns ice stream, West Greenland. Ice 90, 9-10.

Funk, M. and H. Röthlisberger. 1989. Forecasting the effects of a planned reservoir which will partially flood the tongue of Unteraargletscher in Switzerland. Ann. Glaciol., 13, 76-81.

Hughes, T.J. 1986. The Jakobshavns effect. Geophys. Res. Lett., 13(1), 46-48.

Hughes, T.J. and M. Nakagawa. 1989. Bending shear: the rate-controlling mechanism for calving ice walls. $\mathcal{J}$. Glaciol., 35(120), 260-266.

Jania, J. 1986. Calving processes of south Spitsbergen tidewater glaciers. Abstract of paper presented at the American Geophysical Union: Chapman Conference on Fast Glacier Flow, Vancouver, B.C., Canada, May 1987.

Lingle, C.S, T.J. Hughes, and R.C. Kollmeyer. 1981. Tidal flexure of Jakobshavns glacier, West Greenland. 7. Geophys. Res., 86(B5), 3960-3968.

Meier, M.F. and A. Post. 1987. Fast tidewater glaciers. J. Geophys. Res., 92(B9), 9051-9058.

Meier, M.F., L.A. Rasmussen, R.M. Krimmel, R.W. Olesen, and D. Frank. 1985. Photogrammetric determination of surface altitude, terminus position, and ice velocity of Columbia Glacier, Alaska. U.S. Geol. Surv. Prof. Pap. 1258-F.

Pelto, M.S., T.J. Hughes, and H.A. Brecher. 1989. Equilibrium state of Jakobshavns Isbræ, West Greenland. Ann. Glaciol., 12, 127-131.

Pillewizer, W. 1965. Bewegungsstudien an einem arktischen Gletscher. Polarforschung, Jahrg. 34, 1964, 5(34), 247-253.

Powell, R.D. 1984. Guide to the glacial geology of Glacier Bay, s.e. Alaska. Anchorage, AK, Alaska Geological Survey. Wilhelm, F. 1963. Beobachtungen über Geschwindigkeitsänderungen und Bewegungstypen beim Eismassentransport arktischer Gletscher. International Association of Scientific Hydrology Publication 61 (General Assembly of Berkeley 1963 - Snow and Ice), 261-271.

The accuracy of references in the text and in this list is the responsibility of the authors, to whom queries should be addressed. 